\title{
Introduction to Maureen O'Connor's SPSSI Presidential Address
}

\section{James S. Jackson}

Institute for Social Research, University of Michigan

It is a pleasure for me to introduce Maureen O'Connor's 2012 SPSSI Presidential address. I would like to briefly touch upon three aspects, career, social justice Commitment, and her humanity and warmth that mark Maureen's professional and personal characteristics in my introduction. It has been an honor and positive learning experience for me to have shared this leadership experience and specifically to have served as president and past president under Maureen's leadership. First, Dr. Maureen O'Connor is Professor of Psychology and Executive Officer of the Doctoral Program in Psychology at the Graduate Center, City University of New York. She has been on the Psychology faculty at John Jay College of Criminal Justice since 1997, and was Chair of that Department from 2002 to 2008. Dr. O'Connor also has appointments on the faculty of the doctoral programs in Psychology and Criminal Justice at the Graduate Center of the City University of New York. She received her JD and her PhD in Law, Psychology, and Policy, from the University of Arizona (with a minor in Organizational Behavior). She has held numerous governance positions in the Society for the Psychological Study of Social Issues (SPSSI). She also served as an elected member of the American Psychological Association's Policy and Planning Board, an APA and SPSSI Fellow, and long-time member of the American Psychology-Law Society. She has served in numerous SPSSI governance positions, including on SPSSI Council, as the Division 9 APA Council representative, and of course as President. She has also been very active in other aspects of APA governance. However, beyond her effectiveness and service as President of SPSSI, Maureen has done much, much more. Among her countless contributions, Maureen served on SPSSI Council, served as APA Council representative, was co-chair of the Policy Committee, was a member and chair of the Applied social Issues award committee and assisted in

Correspondence concerning this article should be addressed to James S. Jackson, Daniel Katz Distinguished University Professor of Psychology and Director of the Institute for Social Research, University of Michigan, Ann Arbor, MI 48109 [e-mail: jamessj@umich.edu]. 
leading the policy programming for the 2006 biennial conference, helping to plan a Town Hall on Scientific Integrity and Symposium on Using Science to Inform Policy.

Her research interests are in the intersection of psychology, gender, and law. Another scholarly interest is in the use of scientific information and expert testimony in the legal system, particularly focused on gendered components of that process. She is a member of the bar in Arizona and Washington, D.C. Her projects have included examining the influence of gender of the expert on expert witness experiences, the effect of type and quality of forensic science evidence on mock juror responses, and jurors' responses to defendants raising an insanity defense. Her numerous articles over the years, reflected in her many professional leadership positions, have made incredible contributions to our understanding of the intersection of the law, psychology, and public policy.

During her presidency, she continued her long-term interest and work on how SPSSI might more effectively incorporate a policy focus into the core of its activities. Maureen has been praised by many in SPSSI for her commitment to the goals of the society and her real organizational and personal skills in "getting things done." All of these abilities and commitments were on display during her presidency in SPSSI. She made a point of increasing SPSSI's focus on teaching, mentoring, and professional development of graduate students and early career scholars. She further enhanced SPSSI's policy efforts by increasing Central Office staffing capabilities in the policy area, especially her work on the Dalmas Taylor Fellows and Marshall Scholars, conducting a survey of members regarding their interests and expertise relevant to policy issues, helping to coordinate the SPSSI Policy Statement on Torture and Interrogation, increasing SPSSI's focus on internationalization, and finally helping to organize and presiding over the 2012 biennial SPSSI conference in Charlotte, NC.

I think that in many ways Maureen's focus came to fruition in the Biennial Stand-alone conference in Charlotte, NC, in June 2012, and the Division 9/SPSSI programming at this APA Conference in Orlando. Her intense focus on social justice and policy came to a fine point in what she called the E-streams, Education, the Environment, and Ethics/Equity. This was accomplished by the Early Career Scholars Workshop, the focus on the Environment brought a number of young scholars who had not previously found a professional home for their focused attention on the psychology of the environment and social justice, a series of outstanding panels addressing education. A second highlight I am sure for Maureen was the emphasis on teaching and mentoring. A third area that was in clear focus at both conferences, but which also was present in SPSSI activities throughout the year, was the attention to policy. But it was the 9th Biennial Conference in Charlotte, NC, that focused SPSSI's opposition to North Carolina's recent passage of SB 514, a law which bans legal recognition of same-sex marriage. Maureen spearheaded a program of activities and events to bring marriage equality 
and research on LGBT issues to the forefront of the Conference and to draw psychologists and local advocates together to discuss the policy challenges that lie ahead in North Carolina and throughout the United States. A special symposium: "The North Carolina Marriage Equality Amendment: Psychology, Policy, and Advocacy" was held, featuring President-Elect Allen Omoto as chair of this special session on same-sex marriage in North Carolina with speakers Clay Eddleman, $\mathrm{MD}$, a local civil rights campaigner and Emeritus Professor of Psychiatry and Behavioral Sciences at Emory University's School of Medicine, Erica Wise, PhD, Clinical Professor \& Director of Psychological Services at The Department of Psychology Community Clinic, University of North Carolina, Chapel Hill and incoming President of the North Carolina Psychological Association, a group that actively worked against the discriminatory measure, and Alex Ingrams, the SPSSI Policy Coordinator

Second, she coordinated the draft of a letter to the Governor of North Carolina expressing SPSSI's concern about SB 514 and similar marriage bans, including pointing out the negative effects of this legislation on our conference. The letter was available for attendees to add their signatures throughout the conference, and was posted on the SPSSI website. SPSSI also prepared a dual-purpose flyer for conference attendees. One side of the flyer lists all of the Conference sessions and presentations related to same-sex marriage and LGBT issues. The other side of the flyer offers specific advocacy tips and resources for same-sex marriage support in North Carolina and beyond. And finally, Marriage equality stickers were available at the conference for distribution to attendees to wear to express their support for marriage equality.

Thus, as usual, and what has been the highlight of her career, professional commitment to SPSSI, and her personal life, Maureen not only "talked the talk but she also walked the walk" during her presidency! It is appropriate that she entitled her talk: Hot tea, flexed muscles, and enacting the mission of SPSSI. 